\title{
A HUMAN RIGHTS BASED EVALUATION OF THE CROATIAN ASYLUM SYSTEM IN THE CONTEXT OF EUROPEANISATION
}

\begin{abstract}
Marko Gregović
Summary: This paper evaluates the asylum system in Croatia in the context of Europeanisation. It uses a human rights based assessment to analyse and evaluate the shortcomings in the system. These shortcomings are then attributed to either 'indigenous' Croatian provisions or to the provisions 'inherited' through the process of Europeanisation. The cumulative findings are translated into practical recommendations on how to improve the Croatian asylum system.
\end{abstract}

\section{Introduction}

In the 1990s, hundreds of thousands of people who were forcibly removed from their homes under the policy of 'ethnic-cleansing' or who fled from war and genocide in Bosnia found refuge in Croatia. ${ }^{1}$ At the same time, thousands of people fleeing from violence in Croatia sought refuge elsewhere in the world. In Croatia, the word 'refugee' is still strongly linked to the victims of wars in former Yugoslavia.

Although the problem of refugees from the Yugoslav wars has still not completely been resolved, other people seeking protection from persecution are increasingly coming to Croatia. Under the auspices of the EU, Croatia has developed an asylum system that allows for people fleeing their countries to find safe haven on Croatian territory. It is expected that there will be a surge in the number of asylum seekers coming to Croatia after Croatia's very probable accession to the EU.

In the context of the possibility that Croatia will become a country of destination rather than merely a transition country on the way to Western Europe, this paper will attempt to look at the human rights protection that Croatia offers current and future asylum seekers. What rights do asylum seekers have in Croatia? What rights are they lacking? How is the existence or lack of rights connected to accession to the EU? These are some of the questions that this paper seeks to answer.

Independent scholar.

1 For example, UNHCR reports that in 1991 and 1992 there were 550,000 internally displaced persons on the territory of Croatia with an additional 400,000 refugees from Bosnia. To put this into context, Croatia's population is 4.5 million. 
Although it is the Croatian state that is ultimately responsible for the human rights standards in its own territory, Croatia does not exist in a vacuum. It is aspiring to join the $\mathrm{EU}$, and the $\mathrm{EU}$ has certain expectations and demands that Croatia has to meet in order for it to join. When it comes to the question of asylum, these demands are formulated in several directives that the Member States and aspiring members are expected to adopt. This paper will analyse the extent to which Croatia has adopted European asylum standards and at the same time evaluate to what extent the Croatian asylum system is currently in line with international human rights standards. I will argue that a large number of deficiencies in the human rights standards of the asylum system in Croatia can be attributed to the fact that the adopted EU directives themselves are not in line with human rights standards.

The purpose of this paper is to develop meaningful recommendations on how to improve current Croatian asylum law, policies and practice in order for it to be better aligned with human rights standards. Establishing whether human rights deficiencies stem from the EU asylum acquis or from Croatia's own bad policies and practices will allow for the more precise attribution of responsibility for the deficiencies, which can translate into concrete policy shifts at the national level. The assumption of this paper is that the deficiencies that are not the product of the adaptation of EU directives but are 'indigenous' will be rather easier to overcome for political reasons.

Croatia has been chosen for this study not only because the author is more familiar with the system in Croatia and has easier access to data, but also because it can serve as a model for other countries aspiring to join the EU. Croatia will undoubtedly be the next country to accede to the EU and, as such, the level of its alignment with EU directives is likely to be the highest of the non-EU countries. Thus, the results of this paper regarding the human rights situation of asylum seekers in Croatia might prove useful to other countries in the region that do not yet have a developed asylum system (Serbia, Montenegro, etc). Specifically, the results could prevent the adoption by these countries of the same bad regulations and practices that are not in line with human rights standards.

\section{Europeanisation and the Croatian asylum system}

This paper uses the concept of Europeanisation, ie the process of exporting EU policies into other countries, to explain the emergence and development of the asylum system in Croatia. This system will be assessed from the perspective of human rights and it will be compared to international and European human rights standards. Recommendations will be given on how to overcome the deficiencies in human rights that do not stem from the process of Europeanisation. 
This paper will thus answer three questions:

a) What are the shortcomings of the Croatian asylum system when it comes to the human rights of asylum seekers, refugees and people under subsidiary protection? ${ }^{2}$

b) Which of the shortcomings are the product of Europeanisation (as manifested in the adoption of EU directives) and which of the shortcomings are the sole responsibility of Croatia?

c) What can be done to address the human rights deficiencies that are the sole responsibility of Croatia?

As can be seen from the questions, this paper will assume three things. Firstly, that there are indeed some shortcomings in the Croatian asylum system. The rationale for this assumption is that human rights are constantly evolving and that there is hardly a system perfectly aligned with human rights standards. Secondly, that at least some deficiencies in human rights might stem from the process of Europeanisation. Thirdly, that it is easier to change in a positive direction provisions and practices that are not dependent on the EU.

Figure 1 represents the scope of this paper. The white section represents the international human rights framework and the components of the European acquis and the Croatian asylum system that are in line with human rights. The heavily shaded section (on the right) represents parts of the European acquis that are not compatible with human rights standards and which have been incorporated into the Croatian system. The lightly shaded section (on the left) represents human rights deficiencies that are 'indigenous' to the Croatian asylum system. In the context of this figure, the intention of this paper is to establish which components of the Croatian asylum system belong to the lightly shaded section and which to the heavily shaded section, and hence to establish the relative responsibility for the deficiencies in human rights.

2 Asylum seekers are people who have expressed their intention to be granted protection in another country. Refugees are asylum seekers who have been granted full protection. People under subsidiary protection are those who do not qualify for refugee status but who cannot be returned to their countries. These concepts will be discussed in more detail later. 


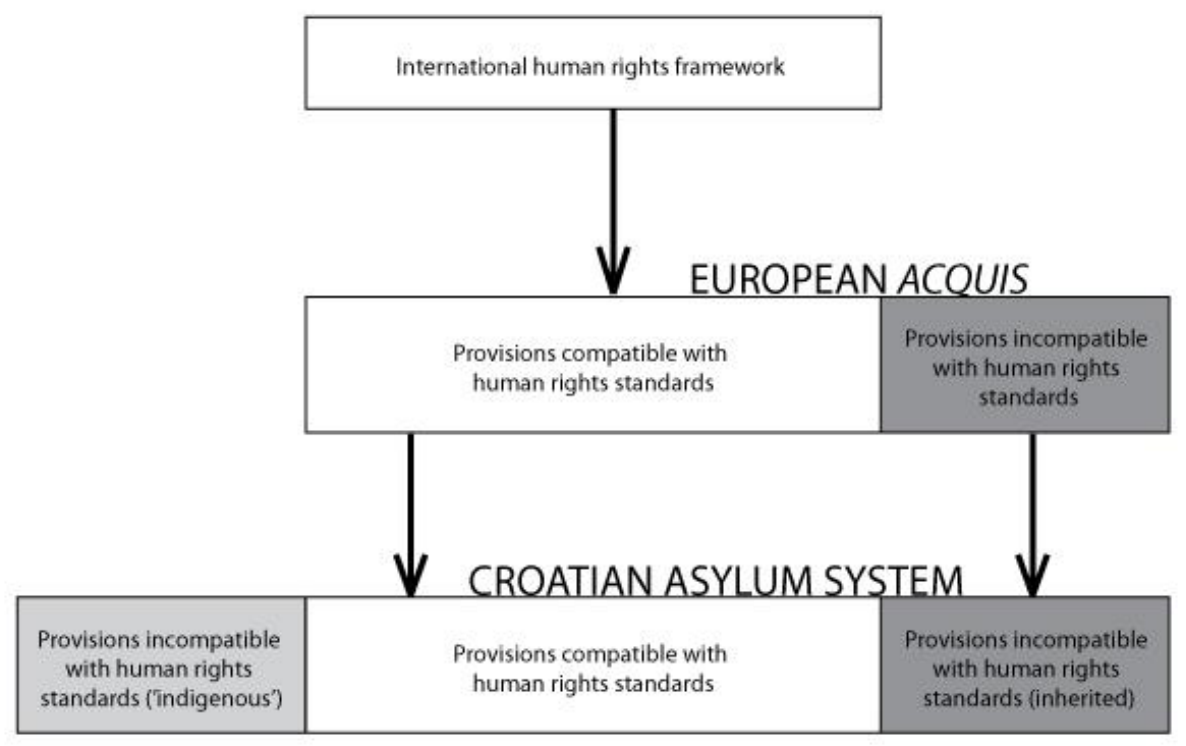

Figure 1.

Although human rights protection is the prime responsibility of the State (Croatia), I assume that under the pressure of Europeanisation, Croatia has less freedom to decide on certain policies, less freedom to change deficient provisions and thus less responsibility. It is the assumption of this paper that Croatia is more likely to change the provisions and practices that are incompatible with human rights standards if these provisions and practices are not dependent on the EU. The recommendations on how to diminish the lightly shaded section, ie the provisions and practices that are the sole responsibility of Croatia will be the main objective of this paper.

This paper will limit itself to the human rights of people seeking protection on the territory of Croatia. It will also limit itself to the legal categories of asylum seekers, refugees, and people under subsidiary protection. It will not cover other people fleeing their homes from dangers that are not part of the legal frameworks, though the problems of such categories of people will be briefly mentioned. Although there is the possibility of being granted temporary protection in the Croatian and European legal framework, this work will not cover this category of people because it is only applicable in cases of a sudden mass influx of persons. Such potential situations are substantially different from the normal state of affairs and as such do not fit into the scope of this work.

Although an in-depth analysis and assessment of the human rights situation for people seeking protection will be conducted, the limits of the paper do not allow space to be given to people with special needs. Thus, 
children and people with physical and mental disabilities, trafficked women, and victims of torture or sexual violence will not be specifically considered. Their special circumstances require another extensive study, but in this paper they will only briefly be mentioned in the appropriate sections.

This paper will focus on the shortcomings of the human rights situation in Croatia. Its intention is not to give a complete analysis of all the rights that are available to asylum seekers and people under protection ${ }^{3}$ because that would require much more space. Since the purpose of the paper is to provide meaningful recommendations, the focus will be on the negative aspects of the asylum system in Croatia.

\section{Contemporary theory on asylum}

This paper will use two distinct conceptual frameworks on two levels of discussion on asylum. On the first level, the framework of Europeanisation will be adopted to explain the emergence and development of the asylum system in Croatia. On the second level, the legal-positivist understanding of the human rights framework will be adopted to assess the compatibility of the asylum system in Croatia with international human rights standards.

\section{The concept of asylum}

Gibney ${ }^{4}$ describes the long history of asylum (deriving from the Greek word asylos, meaning that which is inviolable) in Western civilisation from churches in the Middle Ages serving as sanctuaries for victims of prosecution and persecution to present-day international human rights law. However, while asylum was earlier a moral category, he claims that today it is a legal one. However, the fact that asylum is today codified in law has not made it much clearer or access to it much easier. Gibney, for example, complains that asylum is "both vague and ill-defined" in international law and points out the sad state of affairs where the word does not even appear in the most significant treaty relating to the status of refugees (the Refugee Convention, hereinafter: RC).

Boswell $^{6}$ would disagree with the characterisation of asylum as a primarily legal category. She talks of asylum as part of a set of European liberal and universalist values that are today under attack from nationalism of two different kinds. The first nationalism is xenophobic

\footnotetext{
This term will be used for both refugees and people under subsidiary protection.

4 M Gibney, The Ethics and Politics of Asylum Liberal Democracy and the Response to Refugees (CUP 2004).

5 Gibney (n 4) 24.

6 C Boswell, 'European Values and the Asylum Crisis' (2000) 76(3) International Affairs 537, 557.
} 
ethno-nationalism which seeks to deny the right to asylum on the basis of ethnicity, while the other is 'welfare nationalism' which wants to deny this right on the basis of the idea that asylum seekers 'cost' too much. She argues that it is unlikely that the first type of nationalism will prevail, but warns about the second type that creates fear about 'bogus' asylum seekers and causes governments to establish very restrictive measures in order to cut 'wasteful' spending on asylum seekers.

In the period after the Second World War, there was a great demand for labour in Europe in order to rebuild the continent. Gibney claims that 'economic requirements of capitalist production almost rendered superfluous distinctions between immigrants, asylum seekers, and refugees in the period up to the 1960 s'. $^{7}$ However, that does not hold true anymore. Asylum seekers and refugees are very much distinguished from economic migrants in both the legal and practical sense. Morris calls this 'stratification of migrants' rights' wherein certain categories of migrants are perceived as having greater rights. ${ }^{8}$ This fits well together with Boswell's warning about tendencies of states to create 'two-tier' systems that distinguish 'bogus' from 'genuine' asylum seekers.

Although Boswell's analysis is certainly useful to establish the political and ethical background to the problem of asylum, this paper will adopt Gibney's idea that the concept of asylum is today largely a legal category dependent on the legal framework within which it is established. In this paper, the most relevant legal framework is, naturally, Croatian. Within this framework, similar to many others, there is a formal distinction between economic migrants and asylum seekers. This paper will focus solely on asylum seekers and other legal categories of protection and not on irregular or economic migrants, no matter how the distinctions between these categories seem superfluous, following Boswell's and Morris' analysis. Asylum will thus be taken as a legal category, present in national, European and international legal documents and analysed from the point of view of legal positivism.

\section{Europeanisation of asylum?}

The question of the ability of institutions to spread their influence globally came from the "globalisers" camp, a group of scholars who argue that the nation states have a diminishing role in today's world. They tend to stress the increasing role of supranational and international institutions in this age of globalisation..$^{9}$ In the context of this paper, this is rela-

\footnotetext{
Gibney (n 4) 25.

8 L Morris, Managing Migration: Civic Stratification and Migrants' Rights (Routledge 2002).

9 Cf Y Soysal, Limits of Citizenship: Migrants and Postnational Membership in Europe (University of Chicago Press 1994); S Sassen, Globalization and its Discontents (New Press 1998).
} 
ted mainly to the question of the ability of the EU to project its influence onto non-EU member states.

This process has been conceptualised and described by several scholars. Lavanex, for example, describes the way in which non-EU countries adopt EU policies and calls this 'EU external governance in "wider Europe".' She defines external governance as 'the extension of the legal boundary of authority beyond institutional integration'. ${ }^{10}$ Olsen describes the same process, but he calls it 'Europeanisation'. He describes its different aspects, but for the purposes of this paper the most important feature that he mentions is 'exporting forms of political organisation and governance that are typical and distinct for Europe beyond the European territory'. ${ }^{11}$ This definition of Europeanisation will be adopted in the present text.

Olsen claims that in the process of Europeanisation there are unequal positions. He noticed, in relation to the accession negotiations with Central and Eastern European countries that "phrases like "catching up" with the west, the conditionality of aid and the need to accept EU standards and forms as part of becoming Member States, indicate status and power differentials'. ${ }^{12}$ The approach that Olsen takes is usually considered a top-down approach, because it stresses the influence of the EU on the nations and not vice versa. ${ }^{13}$ Such an approach is suitable for this paper because it fits very well into the observed tendencies - Croatia 'adapts' itself and aligns its legal framework with that of the EU, and there are no indications of reciprocity.

There have been a number of studies that link the development of asylum systems in non-European countries to the EU. Feijen calls this process 'the asylum-enlargement nexus', ${ }^{14}$ Phuong calls it 'the enlargement of Fortress Europe', ${ }^{15}$ and Collinson refers to it as 'the development of an asylum buffer-zone'. ${ }^{16}$ We can easily subsume the processes that

\footnotetext{
10 S Lavenex, 'EU External Governance in "Wider Europe”' (2004) 11(4) Journal of European Public Policy 680, 683.

11 JP Olsen 'The Many Faces of Europeanization' (2002) 40(5) Journal of Common Market Studies 921, 924.

12 Olsen (n 11) 938.

13 An alternative to the top-down approach would be the bottom-up approach which would stress the influence that individual nations have on the development of policies and practices of the EU.

14 L Feijen 'Facing the Asylum-Enlargement Nexus: The Establishment of Asylum Systems in the Western Balkans' (2008) 20(3) International Journal of Refugee Law 413.

15 C Phuong, 'Enlarging "Fortress Europe": EU Accession, Asylum, and Immigration in Candidate Countries' (2003) 52(3) International Comparative Law Quarterly.

16 S Collinson, "Carrier Sanctions, "Safe Third Countries" and "Readmission": The Development of an Asylum "Buffer Zone" in Europe' (1996) 21(1) Transactions of the Institute of British Geographers 76.
} 
these authors talk about under the previously described concept of (topdown) Europeanisation. The way that this Europeanisation of asylum systems takes place is through negotiation processes with countries aspiring to join the EU. Phuong argues that 'current EU member states $[\ldots]$ are putting considerable pressure on candidate countries to set up efficient asylum systems, and more importantly to them, strict border controls' ${ }^{17}$ Feijen similarly argues that 'one of the conditions for [the] eventual accession [of candidate countries] is the establishment of EU compatible asylum systems $[\ldots]^{\prime} .^{18}$

What these authors argue is that it is in the EU's interest to create asylum systems and stricter border regimes in the non-EU countries of Eastern and Southeastern Europe. For example, Collinson claims that $\mathrm{EU}$ interests lie, on the one hand, in the creation of 'an additional control zone protecting or distancing western Europe from actual or potential refugee movements' and on the other hand, countries with such systems 'absorb asylum-seekers and other migrants who would otherwise be destined for western Europe'. ${ }^{19}$

There is disagreement on whether the Europeanisation of asylum has a positive or negative effect on refugee protection. Thielemann and El-Enany claim that 'European cooperation on asylum and refugee policy has strengthened, not undermined, refugee protection in Europe. ${ }^{20}$ They argue the importance that 'the setting of minimum standards has had in ending the race to the bottom in Member States' asylum provisions'. ${ }^{21}$ Similarly, Feijen argues that the EU successfully created asylum systems in the Western Balkans that are "by and large, compatible with international and EU standards'. ${ }^{22}$ Phuong, on the other hand, has a different position, arguing that:

[...] grave concerns must be expressed about the lack of strong guarantees against direct and indirect refoulement. [...] Despite EU pressure, candidate countries must not forget that they have international obligations not to return people to situations where their life or security would be at risk. ${ }^{23}$

This paper will use the concept of the Europeanisation of asylum and, among other things, try to contribute to the debate on the effect of

\footnotetext{
17 Phuong (n 15) 641.

18 Feijen (n 14) 413.

19 Collinson (n 16) 79.

20 E Thielemann and N El-Enany, "The Myth of "Fortress Europe": The (True) Impact of European Integration on Refugee Protection'<www.jhubc.it/ecpr-riga/virtualpaperroom/112. pdf $>$ accessed 20 March 2010) 1.

21 Thielemann and El-Enany (n 20) 23.

22 Feijen (n 14) 429.

23 Phuong (n 15) 662.
} 
this process on refugee protection in Croatia. Through the analysis of the Croatian asylum system and an assessment of the human rights shortcomings that can be attributed to Europeanisation, it will supply empirical material for the debate on the nature and value of this process.

\section{Methodology}

The main methodological problem that this paper faces is Croatia's position between full sovereignty and membership of the EU. Croatia already has an asylum system in place, but it is adapting it to meet EU requirements. Thus, this paper is looking at a moving target, an asylum system that is not yet completely set. At the same time, the EU asylum system is also changing - it is currently in the final stage of becoming a common system. Thus, this paper has to aim at describing and critically assessing two moving targets and their relationship with one another. The overview of these systems will be presented later.

This paper consists of two distinct parts. In the first part, a qualitative content analysis is used on selected international and European human rights documents. The purpose is to find a list of rights that are applicable to asylum seekers and people under protection in Croatia. This list of rights, together with a brief summary of conclusions, can be found in the last section of this paper.

In the second part of the paper, the extent of (potential) human rights violations and the degree of Europeanisation are evaluated. The degree of the Europeanisation of the asylum system in Croatia is analysed by checking the alignment of the Croatian system with EU directives relating to asylum, which is done by comparing the Croatian provisions and practices with the provisions of the EU directives.

In the same manner, the level of human rights deficiencies stemming from the EU is analysed by checking if these deficiencies stem directly from the EU directives or if the deficiencies are 'indigenous' to the Croatian context. This is done mainly through legal analysis, but also by using secondary sources to establish deficiencies in the EU directives that have been incorporated in the Croatian system. It is not enough to simply look at the legal provisions (although they are examined most closely); primary data are needed to supplement the legal analysis in order to see how the asylum system looks in practice and to better establish the existence and extent of (possible) human rights violations.

It is important to note that a large part of this paper - the analysis of the current Croatian asylum system - represents the only such research performed in Croatia and thus it was impossible to refer to secondary sources. References to secondary sources are reserved for parts of the Croatian system that incorporate EU directives analysed by others. 
This paper uses a variety of data collection methods to assess the human rights situation of asylum seekers and refugees in Croatia. It uses a legal analysis of relevant national, European and international laws (the Asylum Act, the International Bill of Human Rights, the European Convention on Human Rights...), and procedural regulations and directives (EU directives, Croatian regulations concerning the accommodation and reception of asylum seekers).

This paper also uses a short field survey of the Asylum Seekers Reception Centre in Kutina and of the Aliens Reception Centre in Jezevo. The author was guided by the officials there, so there is a possibility that certain important aspects of these institutions remained hidden from the author, but the author's impression is that he managed to see the relevant parts and facilities in these centres.

The interviews that were conducted were semi-structured with initial topic areas prepared in advance, which allowed broad responses and subsequent follow-up questions. The sampling used was purposive, and respondents were chosen so that their responses cover all the areas of the Croatian asylum system. The interviewees were thus government officials, personnel working with people seeking protection, NGO activists, lawyers and persons seeking protection from the Croatian state. All the interviews were conducted in the course of three months, from January to March 2010. All the interviews lasted between 30 minutes and an hour and covered a broad range of asylum-related topics. All the interviews were recorded with the explicit approval of the interviewees. The topics range from the law and its implementation, the asylum procedure, specific policies, the influence of the EU acquis and directives and the level of Croatian integration. Special care was taken to ask questions that were related to the state of the human rights of people seeking protection. The responses were cross-checked with other data (statistics, other responses, observations) to enhance validity. The privacy of interviewees was guaranteed by the promise that only their functions and/or statuses would be revealed.

The list of interviews follows:

a) Activist of the NGO Centre for Peace Studies (CPS Interview)

b) Focus group with 5 Ministry of the Interior representatives (MOI interview)

c) Head of the Asylum Seekers Reception Centre in Kutina (Kutina interview)

d) Head of the Aliens Reception Centre in Jezevo (Jezevo interview)

e) Asylum Commission representative (Commission interview)

f) Republic of Croatia's Office for Human Rights representative (OHR interview)

g) Croatian Law Centre lawyer (CLC interview) 
h) UNHCR representative (UNHCR interview)

i) Asylum seekers interview (AS interview)

j) Person with refugee status (Refugee interview)

k) Croatian Red Cross representative (CRC interview)

Interviews a), c) and d) were conducted by the author, while the rest was conducted together with members of the Centre for Peace Studies.

For the purposes of quoting documents, interviews and reports, the author provided translation from Croatian to English.

\section{Asylum in the context of the international human rights framework}

In this section, the international legal framework related to asylum will be thoroughly examined. The aim is to establish how asylum is conceptualised in international law, and what the rights are of asylum seekers and refugees. This will serve as the standard against which an assessment will be made of the provisions in the Croatian asylum system.

\section{United Nations framework relating to asylum}

The United Nations framework is crucial for assessing the extent of possible human rights violations in Croatia because it provides the standards against which the empirical findings from Croatia can be compared. This is why the UN documents will be analysed in detail with specific focus on the parts relating to these rights.

\section{Universal Declaration of Human Rights}

The Universal Declaration of Human Rights is the first document that explicitly mentioned asylum in the context of human rights. The declaration states in article 14: 'Everyone has the right to seek and enjoy in other countries asylum from persecution'. There are several problems with this declaration. First and most importantly, the declaration itself is not binding. Secondly, the formulation of article 14 offers grounds for different readings. It is quite peculiar that the formulation stresses the seeking of asylum and that there is no explicit 'right to asylum' as in the case of other rights ('the right to life', 'the right to freedom of thought'...). Reading this formulation conservatively, one can argue that there is no obligation of any state to actually grant asylum to anyone - they only have to provide the opportunity for the person to seek it. Understood in this sense, the right to asylum is not a human right but a procedural right and states do not have any duties towards asylum seekers. This reading seems cynical, for why would there be a right to seek something that is unattainable. One must admit, however, that the formulation of article 14 is very unfortunate because it does not establish the right to asylum beyond dispute. 
There have been attempts to address these concerns. Perhaps the most important was the General Assembly 1967 Declaration on Territorial Asylum. This did not amend the Universal Declaration with anything spectacular, since it retained the right of any state to have full competence in deciding when and how to grant asylum - if ever. However, the declaration did improve if only slightly on the Universal Declaration. In article 3 it stipulates that rejection at the frontier or automatic expulsion is not acceptable. There are, however, some exceptions, such as national security or 'a mass influx of persons'. There was an attempt to further expand the right to asylum at the United Nations Conference on Territorial Asylum in 1977. However, this ended up in failure, since it was 'unable to agree upon a convention in the time allocated'. ${ }^{24}$

From what has been said, it is clear that the right to asylum is not clearly established in the most basic of international human rights treaties. However, this document nevertheless establishes a universally accepted list of human rights that all human beings, including asylum seekers, are entitled to.

\section{The Convention relating to the status of refugees}

The Convention Relating to the Status of Refugees adopted in 1951 (hereinafter: Refugee Convention $(\mathrm{RC})^{25}$ ) and its 1967 Protocol are the most basic international instruments that regulate the status and rights of refugees. At the time of writing this paper, it has been ratified by 144 countries and is considered one of the cornerstones of the international legal framework.

Similar to the Universal Declaration, the RC does not provide unambiguously for the right to asylum. What is more surprising, it does not even mention asylum anywhere in its articles. ${ }^{26}$ It does, however, establish the principle of 'non-refoulement' which is seen as crucial for the right to seek asylum: ${ }^{27}$

No Contracting State shall expel or return ('refouler') a refugee in any manner whatsoever to the frontiers of territories where his life or freedom would be threatened on account of his race, religion, nationality, membership of a particular social group or political opinion. ${ }^{28}$

\footnotetext{
${ }_{24}$ International Law Commission, Right of Asylum (2010) United Nations <http://untreaty.un.org/ilc/summaries/6_2.htm> accessed 6 February 2010.

25 Sometimes this is also referred to as the 'Geneva Convention' although this is not very accurate because the convention does not belong to the set of original four conventions of 1949 that are commonly called the 'Geneva Conventions'.

26 Gibney (n 4).

27 See, for example, UNHCR 2010 'UNHCR Note on the Principle of Non-Refoulement' $<$ www.unhcr.org/cgi-bin/texis/vtx/refworld/rwmain?docid=438c6d972> accessed $6 \mathrm{Fe}-$ bruary 2010.

28 Convention Relating to the Status of Refugees, adopted 28 July 1951, entered into force 22 April 1954, 189 UNTS 137 (Refugee Convention) art 3.
} 
Another important thing that the RC establishes is the definition of a refugee. A refugee is a person that:

[a]s a result of events occurring before 1 January 1951 and owing to well-founded fear of being persecuted for reasons of race, religion, nationality, membership of a particular social group or political opinion, is outside the country of his nationality and is unable or, owing to such fear, is unwilling to avail himself of the protection of that country; or who, not having a nationality and being outside the country of his former habitual residence as a result of such events, is unable or, owing to such fear, is unwilling to return to it.

We can agree with Clark that in the mentioned provisions, the 'Convention gives no right to asylum; however, the Convention and its definition have become an international norm for granting the right to asylum'. ${ }^{29}$

The original purpose of the $\mathrm{RC}$ was to establish the rights of refugees from the Second World War, but the 1967 Protocol extended the definition to other groups of persecuted people by deleting the temporal requirement ('before 1 January 1951') from the Convention. The interesting fact about the Convention is that it is quite narrow at first sight, defining special reasons for persecution, but it also includes 'membership of a particular social group' as a criterion which has been interpreted quite broadly. This feature renders the definition very flexible. Juss gives examples of this flexibility, stating that refugee can include members of a particular family; of members of a Somali clan; of homosexuals; of students; and of parents of Burmese student dissidents'. ${ }^{30}$

Unlike this flexible part, the persecution requirement of the definition is usually deemed restrictive. People who are escaping poverty, hunger, epidemics, or (what is increasingly relevant) environmental disaster are not eligible to be put under the protection of the Convention. Gibney informs us that:

[u]nder the somewhat dubious interpretation of the $\mathrm{RC}$ recently used by France and Germany, women who have fled the oppressive strictures of the Taliban, Iraqis displaced by the US and British war to disarm Saddam Hussein, in addition to Zairians escaping the deadly Ebola virus, may not be considered refugees. For these groups are not on the move because they have been persecuted, in the sense that their state has deliberately targeted them for ill-treatment. ${ }^{31}$

Besides the most important parts of the Convention, the establishment of the non-refoulement principle and the defining of refugees, the Conven-

\footnotetext{
${ }_{29}$ T Clark 'Human Rights and Expulsion: Giving Content to the Concept of Asylum' (1992) 4(2) International Journal of Refugee Law 189, 190.

30 S Juss, International Migration and Global Justice (Ashgate Publishing 2006) 190.

31 Gibney (n 4) 7.
} 
tion also contains other provisions relevant to the situation of asylum seekers. It calls on States 'to facilitate the assimilation and naturalization of refugees' (article 34). There are a number of rights that the Convention explicitly lists as rights of refugees. These rights include the right not to be discriminated on the basis of race, religion or country of origin ${ }^{32}$ (article 3). Next there is the right to practise religion and freedom with regard to the religious education of children (article 4), the right to access a court of law (article 16), the right to elementary education (article 22), the right to public relief (article 23), and the right to be issued identity papers (article 27) and travel documents (article 28). The other important provision is the prohibition of penalising refugees 'on account of their illegal entry or presence $[. .$.$] provided that they present themselves without delay and show$ good cause for their illegal entry or presence' (article 31 ).

One of the most interesting features of the Convention is that it allows for reservations to some, but not all, articles. The definition of a refugee, the protection from discrimination, the right to religious freedom and the right to access the courts and the non-refoulement principle represent the non-derogable parts of the Convention.

There are other rights enumerated in the Convention; however, they are of limited practical value since they go only so far, since they provide that the right should not be less favourable to refugees than to 'nationals of a foreign country in the same circumstances'. This clause renders almost completely ineffective a number of what can be considered basic rights, such as the right to work (article 17), the right to housing (article 21 ), the right to freedom of movement (article 26), etc. Thus, these rights were not included in the assessment of the rights of people seeking protection in Croatia.

\section{Other relevant UN documents}

There are a number of other conventions and declarations that are of interest in the context of asylum.

The International Covenant on Civil and Political Rights (ICCPR) ${ }^{33}$ is not limited to refugees or citizens, but applies equally to all human beings. It lists rights that are lacking from the $\mathrm{RC}$ but to which all aliens and refugees are entitled without exception, such as the right to life (article

\footnotetext{
32 One has to notice that this is quite an unusual non-discrimination clause in its narrowness. We could compare it to the non-refoulement principle in which in addition to race, religion and nationality we have membership of a particular social group or political opinion as relevant categories for discrimination. The Universal Declaration of Human Rights similarly has discrimination defined much more broadly and includes 'race, colour, sex, language, religion, political or other opinion, national or social origin, property, birth or other status'. 33 International Covenant on Civil and Political Rights, adopted 16 December 1966, entered into force 23 March, (1966) 999 UNTS 171 (ICCPR).
} 
3), freedom from torture (article 4), freedom from slavery (article 8), freedom of thought (article 18), and other rights. The International Covenant on Economic and Social Rights (ICESR) ${ }^{34}$ lists other rights, such as the right to work (article 6), the right to social security (article 9), the right to health (article 12) etc. Both ICCPR and ICESCR supplement the RC. Asylum seekers and refugees are among the weakest and most vulnerable groups of people who by definition do not have the protection of their home country and thus have to rely on the international human rights framework which grants them rights not as nationals of any country, but as members of the human race.

There is a peculiar feature of ICESCR worth noting because it is relevant in the context of this attempt to create a list of rights that are applicable to asylum seekers and refugees. Article 2(3) of ICESCR states that:

Developing countries, with due regard to human rights and their national economy, may determine to what extent they would guarantee the economic rights recognized in the present Covenant to non-nationals.

This leaves room for interpretation when it comes to the rights of refugees and asylum seekers. There is ambiguity about who are the developing countries and what they are, and it thus seems that the state has the sole authority to determine what rights should be granted to nonnationals. However, economic, social and cultural rights will nevertheless be included in the assessment of the rights of people seeking protection because the principle of human rights is that these rights should be progressively realised. ${ }^{35}$

The Convention against Torture and Other Cruel, Inhuman or Degrading Treatment or Punishment applies to all people regardless of their refugee status. It echoes the RC and its principle of non-refoulement with article 3 and the prohibition on expelling any person if there are grounds for belief that he or she will be in danger of being subjected to torture. This requirement is absolute and, unlike the RC, States cannot restrict this right on the grounds that a person constitutes a danger to the security of the country.

This section has not exhausted all the human rights treaties that exist and that affect asylum seekers and refugees. It has considered only those that are crucial for the consideration of the state of human rights of such people in Croatia. Human rights that were taken as the benchmark can be found in the list in the final section of this paper.

\footnotetext{
34 International Covenant on Economic and Social Rights, adopted 16 December 1966, entered into force 3 January 1976, 993 UNTS 3 (ICESR).

35 M Freeman, Human Rights: An Interdisciplinary Approach (Blackwell Publishers 2002).
} 


\section{The European asylum system and Croatia's accession to the EU}

While the previous section discussed the right of asylum and the human rights that are relevant to asylum seekers and people under protection, this section will discuss the development of the asylum system in the EU and Croatia, and will present a basic explanation of the Croatian accession process to the EU. This section will thus briefly contextualise the analysis and discussion in succeeding chapters.

\section{Asylum in the context of the EU}

Since the 1980s, European countries have progressively integrated within a broader supranational set of institutions and laws. In this context, one of the milestones of EU integration was the signing of the Schengen agreement in which five countries (Belgium, France, Luxemburg, the Netherlands, and West Germany) created a common zone with a free movement of people and goods. Today, 25 out of the EU's 27 Member States are parties to the agreement. Along with the creation of this borderless area, the borders with non-EU countries were strengthened.

After the abolition of internal borders with the 1995 Schengen Agreement and the integration of that agreement into the EU with the 1997 Amsterdam Treaty, the EU started developing a common asylum policy. The Tampere Summit of 1999 was where European states put forward the initiative of creating a Common European Asylum System (CEAS). The first, legislative, stage of establishing the CEAS had as a goal:

[...] to level the asylum playing field and lay the foundations for a Common European Asylum System, on which could be built further structures to safeguard the EU as a single asylum space and ensure that our citizens could have confidence in a system that gave protection to those who required it and dealt fairly and efficiently with those without protection requirements. ${ }^{36}$

As a result of the first stage, four instruments were implemented in the Member States: the Dublin Regulation, ${ }^{37}$ the Reception Conditions Directive (RC), ${ }^{38}$ the Qualification Directive (QD), ${ }^{39}$ and the Asylum

\footnotetext{
36 Commission, Home Affairs (2010) The European Union Policy for a Common European Asylum System <http://ec.europa.eu/justice_home/fsj/asylum/fsj_asylum_intro_en.htm> accessed 20 May 2010.

37 Council Regulation (EC) No 343/2003 of 18 February 2003 establishing the criteria and mechanisms for determining the Member State responsible for examining an asylum application lodged in one of the Member States by a third-country national [2003] OJ L50/1. 38 Council Directive 2003/9/EC of 27 January 2003 laying down minimum standards for the reception of asylum seekers [2003] OJ L131/18.

39 Council Directive 2004/83/EC of 29 April 2004 on minimum standards for the qualification and status of third country nationals or stateless persons as refugees or as persons who otherwise need international protection and the content of the protection granted [2004] OJ L304/12.
} 
Procedures Directive (APD). ${ }^{40}$ These directives are instruments of crucial importance for the process of Europeanisation, where the extent of this process will be measured by the extent of the incorporation of directives into the Croatian asylum system.

Recently, there have been proposals to further amend these directives with clear rules on detention, ensuring better living conditions and better access to labour market, ${ }^{41}$ and to better address potential abuse, speed up procedures and establish clear rules on repeated applications, among other things. ${ }^{42}$ However, due to the fact that they are so recent, these proposals have not yet influenced the Croatian asylum system and as such will not be further considered in this paper.

The Hague programme of 2004 reiterated the conclusions of the Tampere Summit and set forth the plan for the second, final stage that was supposed to be completed in 2010. The purpose of this stage was to:

look to the establishment of the common asylum procedure and uniform status for those granted asylum or subsidiary protection, based on a thorough and complete evaluation of the legal instruments adopted in the first phase. ${ }^{43}$

The deadline for the creation of the CEAS is 2012. The European Asylum Support Office, established in Malta, is yet another key component of the CEAS with the purpose of harmonising not only legislation but also practice related to asylum. This office supports EU Member States under particular pressure, establishes databases and provides support for practical cooperation. ${ }^{44}$ From the perspective of human rights, the establishment of this office is a step in the right direction since, among other things, there are vast discrepancies in approval rates within the $\mathrm{EU}$, and harmonising them is crucial for the establishment of a European asylum system that is fully compatible with human rights.

The Lisbon treaty entered into force in December 2009. Its provisions envisage the establishment of uniformity across Member States in the rights of refugees and people under subsidiary protection. It also

\footnotetext{
40 Council Directive 2005/85/EC of 1 December 2005 on minimum standards on procedures in Member States for granting and withdrawing refugee status [2005] OJ L326/13.

${ }^{41}$ Commission, 'Amended Proposal for a Directive of the European Parliament and of the Council laying down standards for the reception of asylum seekers' COM (2011) 320 final.

42 Commission, Amended Proposal for a Directive of the European Parliament and of the Council on common procedures for granting and withdrawing international protection status COM (2009) 0554.

43 Commission, 'Amended Proposal for a Directive of the European Parliament and of the Council on common procedures for granting and withdrawing international protection status' COM (2011) 0319 final.

${ }_{44}$ Regulation (EU) No 439/2010 of the European Parliament and of the Council of 19 May 2010 establishing a European Asylum Support Office [2010] OJ L132/11.
} 
envisages the creation of a common procedure for all Member States and the expansion of the jurisdiction of the European Court of Justice which will be able to adjudicate asylum cases. The Lisbon Treaty confirms at the highest level the European commitment to creating a common asylum system.

The EU's asylum system was further amended with Directive 2011/51/EU of the European Parliament and the Council. This directive extended the scope of previous EU directives for third-country nationals who are long-term residents to beneficiaries of international protection. Refugees and people under subsidiary protection may thus acquire longterm resident status after five years of legal residence in one of the EU Member States.

\section{Other Relevant European Documents}

The EU Charter of Fundamental Rights came into force with the Lisbon Treaty in December of 2009. This document lists the rights of EU citizens. However, since Croatia is not yet a member of the EU, this document will not be further examined because it does not (yet) apply to Croatia. It suffices to note that article 18 of the Charter explicitly mentions the right to asylum and stipulates that it shall be guaranteed according to the RC.

The Convention on the Protection of Human Rights and Fundamental Freedoms of the Council of Europe (also called the European Convention on Human Rights - ECHR) is in many aspects similar to the International Bill of Rights with several important differences. First of all, it is mostly concerned with civil and political rights, ${ }^{45}$ and these are usually defined in more detail than in the Bill. Secondly, and more importantly, unlike the Bill of Rights, it is actually binding on the member states of the Council of Europe. Anyone can bring their case forward to the European Court of Human Rights (ECtHR) if they feel that their human rights have been violated and if all attempts to seek redress in front of national courts have been exhausted.

The Republic of Croatia is a party to the ECHR and its accompanying Protocols 1, 4, 6, 7, 11,12, 13 and 14. As such, complaints against it can be brought to the ECtHR and it is obligated to follow its judgments.

The ECHR does not contain an explicit right to asylum; however, there are some relevant rights that are often used by asylum seekers. By far the most important right is contained in article 3: 'No one shall be subjected to torture or to inhuman or degrading treatment or punishment.'

45 With some social rights added in the subsequent protocols, such as the right to education. 
This article is absolute, meaning that the States cannot derogate from it in any way, even in cases of emergency (article 15 ECHR). There have been several cases before the ECtHR that reaffirmed the prohibition of refoulement by referring to article 3 ECHR. ${ }^{46}$ This is important, because the judgments of ECtHR are binding on the States while other previously mentioned documents belong to the category of soft law.

\section{Croatia's accession to the EU}

There is near consensus among the political elite that the only way forward for Croatia is to join the EU. Although public opinion is quite divided on the issue, there is no single parliamentary party that opposes accession. Understood in this light, it should not be surprising that Croatia is well on its way to becoming a member of the EU. Croatia became a candidate country in June 2004 and accession negotiations started one year later, in October 2005. Croatia completed negotiations with the EU in June 2011. If the Croatian people in the upcoming referendum decide to join the EU, Croatia will become a Member State on 1 July 2013.

The acquis needs to be fully integrated in the domestic legal framework of any candidate country wishing to join the EU. For the purposes of the negotiations with Croatia (and other candidate countries), the EU acquis has been divided into 35 chapters. The European Council adopts a common position for each of these chapters and then negotiations begin on each chapter until an agreement between the EU and Croatia is reached on each of them. Croatia has successfully closed all the negotiating chapters, including Chapter 24: Justice, Freedom and Security, under which the negotiations on the asylum system in Croatia took place.

\section{The development of Croatia's Asylum System}

Croatia is a signatory to the 1951 Geneva Convention and its protocol. This is enshrined in the Constitution. The right to asylum is explicitly mentioned in article 33 which states:

Foreign citizens and stateless persons may obtain asylum in Croatia, unless they are prosecuted for non-political crimes and activities contrary to the basic principles of international law (Constitution of the Republic of Croatia, article 33).

Besides the Constitution, asylum in Croatia is further elaborated in the Asylum Act. However, there has been a series of major changes in the

\footnotetext{
46 See, for example, Soering $v$ the UK; Cruz Varas $v$ Sweden and Vilvarajah $v$ the United Kingdom, TI $v$ the United Kingdom. These cases tie ECHR to the questions of asylum, such as the non-refoulement principle, the safe third country concept, etc. For more on these cases, see N Mole Asylum and the European Convention on Human Rights ( $4^{\text {th }}$ edn, Council of Europe Publishing 2000).
} 
Croatian legal framework when it comes to asylum. To illustrate, I will present a brief history of the development of the present law.

The first law relating to asylum is the 1991 Act on the Movement and Stay of Aliens. It was changed several times and in 1997 the possibility of obtaining asylum in Croatia was finally amended to it. This law was succeeded by the 2004 Asylum Act which was greatly improved in relation to the previous documents. However, it was still criticised by civil society and it was not sufficiently harmonised with the EU acquis. ${ }^{47}$ In 2007 it was changed to form the legislation that is in place in Croatia today. This law was further amended in 2010 in order to comply fully with the EU acquis.

The fact that the law that applies to only several hundred persons annually has been changed numerous times in several years is significant. It suggests strongly that it is not Croatia that is behind the creation and development of the law, but that it is mostly the EU. This is corroborated by the fact that the EU criticised or approved the asylum system in numerous 'progress reports' that it publishes each year. This is the first instance where we can confirm the process of the Europeanisation of the Croatian asylum system.

In the subsequent analysis, reference will be made to relevant EU directives in order to further substantiate the claim that Europeanisation is the process largely responsible for the creation of the Croatian asylum system in its present form.

\section{The current asylum system in Croatia}

In previous sections, the international human rights framework has been analysed in order to establish what rights are relevant to the people seeking protection in Croatia, and the development of the European and Croatian asylum system has been described in order to provide the context. In this and subsequent sections, human rights will be compared to the existing legal framework in Croatia on the one hand and to the practice on the ground on the other hand. In addition, the explicit connections between EU directives and the provisions of Croatian law, policies and practice will be established in order to determine the impact of Europeanisation on the development of the system. This will confirm the hypothesis of the Europeanisation of asylum and will help to establish the primary responsibility for different human rights deficiencies in the asylum system in Croatia.

47 Commission, Croatia 2006 Progress Report SEC COM (2006) 649 final 1385. 


\section{Basic provisions and definitions in the 2007 Asylum Act}

This subsection introduces the current Asylum Act and establishes the first connections between European directives and Croatian law. As we will see, these connections are extensive and the directives here are completely integrated into Croatian law.

The most important provision of the Asylum Act is article 3 which prohibits refoulement in the sense of the RC. Article 4 defines the requirements for granting asylum which also follow from the Convention. Thus, asylum will be granted to an alien

who is outside the country of his normal residence and who, owing to well-founded fear of being persecuted for reasons of race, religion, nationality, membership of a particular social group or political opinion is unable or, owing to such fear, is unwilling to avail himself of the protection of that country.

The definition of persecution is literally transferred from the article 9 of the QD. This provides a very detailed list of acts that are serious enough to constitute a severe violation of rights, including acts of physical, mental and sexual violence, discriminatory legal measures, discriminatory prosecution or punishment, denial of judicial redress, etc.

Actors of persecution can be the State and State organs, parties or organisations substantially controlling the State, and non-State actors if the State or somebody else (including international organisations) is unable or unwilling to provide protection against persecution. This is laid down article 10 which corresponds to article 6 of the QD. This is the first problematic part that we encounter, for it allows non-State actors to offer protection. The ECRE and other organisations have warned that this is unacceptable because non-State actors cannot be parties to international human rights instruments. ${ }^{48}$

Article 6 of Asylum Act adopted the provisions found in articles 11 and 12 of the QD and it lays out the causes of exclusion from refugee status. These include well-founded suspicions that the person involved committed a war crime, a crime against peace or against humanity or a serious non-political crime outside the home country. The inclusion of serious non-political crime as a reason for exclusion is problematic. It could possibly allow the exclusion of people who have, for example, murdered someone but served a sentence outside their country. This provision is too broad and too open for interpretation, which is also the opinion of

48 European Council on Refugees and Exiles (ECRE) (2008) The Impact of the EU Qualification Directive on International Protection' <www.ecre.org/files/factsheetqualification. pdf> accessed 20 April 2010. 
the ECRE ${ }^{49}$ This provision could possibly lead to a breach of article 14(6) ICCPR $^{50}$ because the denial of asylum on the basis of a past crime for which someone was punished would amount to a second punishment.

Subsidiary protection is granted according to the criteria laid down in articles 7 and 8, which correspond to articles 15 and 16 of the QD. It is granted to people who do not qualify for asylum but where there are still grounds for believing that they would face a real risk of suffering serious harm if returned to their country of origin. Persons can be excluded from the possibility of being granted subsidiary protection on similar grounds that can be used for exclusion from asylum. It also includes a provision that the person can be excluded if it is established that the person's only reason for seeking protection is to avoid a prison sentence in his or her home country. This is an interesting point because it is either unnecessary (subsidiary protection cannot be granted anyway if there is no risk of serious harm or injustice) or it actually allows for the return of people who were guilty of some crime punishable by prison, but are in fact in danger of facing serious harm or injustice.

The mentioned exclusion clauses found in the QD and then integrated into the Croatian Asylum Act have been the object of severe criticism. ECRE stated: 'The directive's exclusion clauses do not reflect international law, and leave dangerous scope for states to deny protection to deserving refugees'. ${ }^{51}$

When it comes to definitions, the most interesting definitions that the act puts forward are those of 'safe country of origin' and 'safe third country'. Safe country of origin is defined as the country of origin of an alien which respects human rights, democracy, political stability and legal protection and where the alien is safe from persecution. A safe third country is similarly a country where the alien resided before coming to Croatia where he or she is safe from persecution and refoulement. A safe third country should have an efficient asylum system in place in order to get on to the list of safe third countries.

These concepts were first put forward in the Asylum Procedures Directive. From the perspective of human rights, this Directive has a lot of problems. Several human rights organisations (including Human Rights Watch, the European Council on Refugees and Exiles (ECRE), Save the Children, Amnesty International) even called for the withdrawal of the directive because

\footnotetext{
49 ECRE (n 48).

50 Article 14(6) states: 'No one shall be liable to be tried or punished again for an offence for which he has already been finally convicted or acquitted in accordance with the law and penal procedure of each country'.

51 ECRE (n 48) 6.
} 
it remains in breach of the EU's own commitments as set out in the Charter of Fundamental Rights, which is to become part of the EU Constitution, as well as individual Member States' responsibilities under international refugee and human rights law. ${ }^{52}$

In particular, the novel concepts that were introduced by the APD have been criticised. Safe third country and safe country of origin are problematic insofar as they attempt to create a general rule for the return of asylum seekers without providing necessary safeguards against the risk of refoulement. In relation to the safe third country concept, the ECRE warns:

The European Court of Human Rights has clarified that the application of safe third country procedures does not absolve the country of asylum of responsibility under Article 3 ECHR. This clearly illustrates that transfers to third countries, without sufficient safeguards, are not compatible with the ECHR. ${ }^{53}$

Deporting asylum seekers to 'safe' third countries could in effect lead to chain deportation back to the country that they once fled, which would put them at the risk of torture or degrading treatment.

Similar objections have been put forward for the concept of the safe country of origin. The ECRE emphasises that even if it were possible to designate countries as generically and absolutely safe it must be borne in mind that human rights situations can change rapidly, ${ }^{54}$ We can agree that it is inconceivable that all the residents of one country could be absolutely and always protected from any kind of persecution.

According to the Head of Aliens Reception Centre, Croatia does not yet utilise these problematic concepts, although there are provisions for them in the law. This is because the lists of these countries have not been created yet (Kutina interview). However, it is expected that this situation will soon change, especially after Croatia's accession to the EU.

\section{Procedure and qualification}

Consideration of the procedure is arguably essential, because without a well-established procedure for granting asylum, other human rights cannot be exercised. This subsection thus looks into the procedural provisions of the law and how the procedure looks in practice in order

\footnotetext{
52 Human Rights Watch (2004) 'Call for Withdrawal of the Asylum Procedures Directive' <www.hrw.org/sites/default/files/related_material/eu-letter032204.pdf> accessed 20 April 2010.

53 ECRE, 'Amended Proposal for a Council Directive on minimum standards on procedures in Member States for granting and withdrawing refugee status, as agreed by the Council on 19 November 2004' (2005) CO1/03/2005/ext/CN.

54 ECRE (n 53) 26.
} 
to find potential human rights violations. In the previous section we saw the full integration of European directives into Croatian law when it comes to basic definitions. The same applies to the procedural provisions contained in this section.

The asylum procedure starts when an asylum seeker presents his or her application (article 53 of the Asylum Act). The Ministry of the Interior is responsible for the first-instance decision. There is no requirement for a legal advisor to be present during the hearing which is a necessary part of the decision process (article 54 - corresponding to article 16(4) APD).

An interpreter will be made available to the asylum seeker (article 24 - corresponding to article 10 APD) for the purposes of the procedure. However, the problem is that the interpreter will interpret into a language that the asylum seeker is 'reasonably supposed to understand'. This is highly problematic because a clear understanding between the MOI and the asylum seeker is an essential prerequisite of a fair process.

The application will be rejected if the asylum seeker does not satisfy the requirements for the status of refugee, if he or she could have gained protection in another part of his or her country and if it was reasonable to expect him or her to stay, if it is manifestly unfounded or if the asylum seeker represents a threat to the security of Croatia (article 58). Manifestly unfounded are those applications where the asylum seeker has failed to provide information or has provided false information that is essential for the procedure or if he or she presents contradictory or impossible facts (article 61 - corresponding to article 28 of the Asylum Procedures Directive). It also relates to situations where the asylum seeker has resided on the territory of Croatia for a long time, but has failed to apply for asylum without valid reasons, and to situations where he or she obviously requests asylum for the sole purpose of avoiding expulsion. The ECRE criticises these provisions from the directives that allow for manifestly unfounded applications which were translated into the Croatian asylum system and claims that this list includes circumstances that do not directly relate to the substance or merits of the claim yet could still be used to designate an application as "manifestly unfounded", with unclear and undefined consequences'. ${ }^{55}$

The MOI representative stated: 'It does not matter if the asylum seeker applied for asylum in some other country - that will not be the reason for refusing protection in Croatia. Every application is taken into account individually' (MOI interview). This is a positive practice. However, with Croatian accession to the EU, this will no longer be the case since, according to the Dublin II Regulation, once asylum is refused in one EU country, the asylum seeker is automatically denied asylum in all other countries.

55 ECRE (n 53). 
The application will be declared inadmissible if the asylum seeker already has the protection of another state, such as refugee status or citizenship (article 60 - corresponding to article 25 APD). It will also be inadmissible if the asylum seeker comes from a safe country of origin, unless special reasons are put forward. The same applies if the applicant came to Croatia from a safe third country. The problems with the concepts of safe country of origin and safe third country have been discussed above.

The law provides for an accelerated procedure (article 56 - corresponding to article 23(4) APD). This procedure takes place if the application is manifestly unfounded or if there are grounds for withdrawing the application. A positive provision is that an accelerated procedure cannot be applied to minors or mentally disabled persons. There is a very curious provision that stipulates that an accelerated procedure will take place if an interview with the applicant is not possible because of his bad health condition. A similar provision does not exist in EU directives and this is a cause for concern. The basic presumption is that sick people should be given more benefits, not less, and there is no logical explanation why people in bad health should be subject to an accelerated procedure. This provision could lead to violation of article 26 ICCPR and article 14 ECHR - freedom from discrimination.

Although the provisions for accelerated procedure exists in the Asylum Act, according to the Commission, following the UNHCR recommendations in the last year and a half, accelerated procedures are no longer practised (Commission interview), which is a laudable practice.

The right to asylum cannot be practised if persons who are eligible for this right do not know of its existence. The author observed that in the Aliens Reception Centre ${ }^{56}$ people do not receive clear information on their right to seek asylum. This could potentially lead to the refoulement of people who did not know of the right to seek asylum.

Interviews with asylum seekers show that they often do not understand how the procedure works. They are confused about what their rights are and thus these rights are often not exercised. For example, an anonymous asylum seeker has reported that she did not seek the transcript of her hearing, although she had the right to obtain it (AS interview).

\section{Legal aid}

The previous section has shown that although some provisions exist in the law, they do not have to be necessarily used in practice (accelerated procedure). The same thing will be encountered again in this section where law and practice somewhat diverge.

56 This is the institution which mainly keeps people who are caught illegally on the territory of Croatia and who are awaiting deportation. 
The right to be represented by an attorney in a court of law is an essential part of contemporary legal systems. Although the asylum procedure is different from 'normal' legal proceedings (according to the ECtHR, it does not even constitute a trial, which will be touched upon later), the consideration of legal aid for asylum seekers is extremely important for asylum law, although the procedure is quite complicated for a layman. This is especially true when it comes to people who are fleeing persecution and it is perhaps unreasonable to expect them to be able to represent themselves in front of hostile investigators.

However, asylum seekers are entitled to free legal aid in the Croatian system (article 34 - corresponding to article 15 APD), but, there are several problems with this provision. The right is limited only to appeals and reviews of the first-instance decision and even then it is limited to cases that are 'likely to succeed'. Both Croatian law and the corresponding EU Directive have several weaknesses from the perspective of human rights. First of all, it is not clear why the right to free legal assistance should be limited only to second-instance procedure. Secondly, it seems that the fact that free legal aid is granted only in cases that are likely to succeed means that there is effectively a level of prejudgment which puts some asylum seekers in a worse position.

In practice, legal aid for first-instance procedures is granted to asylum seekers through the Croatian Law Centre (CLC), an NGO. A representative of the organisation stated that they provide first-instance legal aid and UNHCR pays attorney fees for this (CLC interview). CLC decides whether or not they want to represent the asylum seeker. Although this is a positive practice, it is entirely the decision of CLC whether to represent the asylum seeker: 'On the basis of the initial conversation with asylum seekers, we decide if we will represent them,' said the CLC representative. It should be the State's responsibility to take care of the right to legal aid which should be extended to the first-instance procedure.

When it comes to the second-instance procedure, the right to free legal aid has been exercised in practice by all the asylum seekers that appeared before the Commission. A representative of the Commission said that there was no instance where asylum seekers were supposed to cover their legal expenses, although that is possible by law (Commission interview).

Another drawback in the implementation of legal aid lies in the fact that the regulation of free legal aid (article 7 ) stipulates that the procedure in the second instance will proceed even if the (free) legal advisor is not present. This in effect means that the asylum seeker could bear the consequences of somebody else's irresponsibility which is unreasonable. In practice, this does not happen, according to the Commission (Commission interview), because the hearing is always postponed until the 
legal advisor is present. Although this practice is praiseworthy, the legal provision is unsatisfactory.

\section{Appeal}

This section brings probably the biggest deficiency in the Croatian asylum system - the right to appeal. The opportunity for an appeal against the MOI's first-instance decision is granted by article 68 (corresponding to article 39 of the Procedure Directive). An appeal is decided by the independent five-member Asylum Commission which consists of civil servants, a university professor of law and a representative of non-governmental organisations that deal with refugees (articles $13-19$ ). If the Commission rejects the appeal, the asylum seeker has another chance of an appeal at the Procedural Court. However, while the appeal before Commission is still part of the regular procedure, an appeal before the Court is not, and thus it does not stop the expulsion order which can be given after the end of the second-instance proceedings (article 75).

Proceedings have a possible drawback in that the appeal process happens before the Commission and not before a fully functioning court of law. This does not have to necessarily be a bad thing, even though courts are supposed to be better and more neutral arbiters than Commissions. This is also the point of view of the UNHCR, whose representative stated: "The tradition that is established in other countries is that you have an asylum court or an administrative court in the second instance. This is what we have also recommended to Croatia but we know that this requires reform [...]' (UNHCR interview). It is the UNHCR's opinion that this change will happen in a few years.

On the other hand, according to the representative of the Ministry of the Interior (MOI), it has been proven that the Commission is indeed an independent body capable of making decisions due to the fact that the Commission has overturned a large number of first-instance decisions (MOI interview). CLC also thinks that the Commission has proven to be capable and mature, giving the example that the Commission regularly holds hearings, although the law does not oblige it to do so (CLC; Commission interview). The Commission stated: 'We normally take into account article 71 which provides for benefit of the doubt, which the MOI does not utilise' (Commission interview). This could indicate weakness in the way the MOI handles applications.

By far the biggest obstacles for the full realisation of the right to a fair trial are with third-instance proceedings (before the Administrative Court). First of all, this Court does not hold hearings, does not go into the merits of the case, nor establishes the facts of the case; it only looks at the legality of the procedure. Secondly, proceedings before this court do not interrupt the expulsion order. These drawbacks are planned to 
be corrected in 2012 with the establishment of a new juridical system in which the role and operation of the Administrative Courts will be changed. ${ }^{57}$ In the meantime, these drawbacks seriously affect asylum seekers' right to a fair trial. 'There have only been four appeals to our decision and two of them were already rejected; the rest are still being decided on,' said the Commission representative. The disproportion of hundreds of rejected applications and only four appeals could indicate that asylum seekers are deported before being able to file an appeal, or it could mean that they are not informed about their right to appeal against the Commission's ruling. Be that as it may, the fact that asylum seekers can be deported before the final decision has been made is a cause for concern and could lead to a breach of article 2 ICCPR and article 13 ECHR, the right to effective remedy. As the ECRE puts it:

A right of appeal becomes meaningless if the asylum seeker has already been sent to the country where they face persecution, torture, or inhuman or degrading treatment. Applicants for asylum should have an absolute right to remain in the territory of the asylum state until a final decision on their application has been made; anything less than such a right represents a risk of refoulement contrary to the 1951 Geneva Convention, and/or to torture or inhuman or degrading treatment contrary to Article 3 ECHR. ${ }^{58}$

Another drawback in the procedure is similar to that in the Croatian juridical system - proceedings take a lot of time and often approach what is legally termed an 'unreasonable length of proceedings'. ${ }^{59}$ According to the Croatian Red Cross, 'the procedures are terribly long, people wait a long time for any response and the probability of getting any sort of protection is very small' (CRC Interview). The MOI has a different opinion and says that most of the applications are solved within six months with a very small number of cases that take longer. The average time for solving a case is from three to four months according to the MOI (MOI interview). Cases that come to the Administrative Court, on the other hand, usually take around six or seven months to be concluded (Commission interview), which is clearly unacceptable.

The length of proceedings when it comes to an appeal against expulsion could constitute a breach of article 13 ICCPR. ${ }^{60}$ Additionally, although

\footnotetext{
57 UNHCR (2010) Universal Periodic Review: 'The Republic of Croatia' < http://www.unhcr. org/refworld/country,,,,HRV,,4b0282a1d,0.html> accessed 30 March 2010.

58 ECRE (n 53) 8-9.

59 This is corroborated by the fact that by far the largest amount of cases against Croatia before the European Court of Human Rights are related to this human rights violation.

60 Article 13 ICCPR states: 'An alien lawfully in the territory of a State Party to the present Covenant may be expelled therefrom only in pursuance of a decision reached in accordance with law and shall, except where compelling reasons of national security otherwise require,
} 
there is formally no legal discrimination, the length of proceedings has a special weight for asylum seekers in detention or for asylum seekers waiting for expulsion. The length of proceedings before the Administrative Court affects everybody equally, but they are of extremely urgent importance for asylum seekers as a group.

Indirect discrimination is where an apparently neutral provision, criterion or practice, based on formal equality, would put persons of one group into disadvantageous positions compared with some other group. ${ }^{61}$ In this situation, though in theory asylum seekers are put into a position equally disadvantageous as that of other people whose court proceedings are long, the effect for asylum seekers is much graver because the possibility of torture or degrading treatment exists for them. Thus, the length of proceedings could in this case constitute a breach of article 26 ICCPR, article 14 ECHR and article 3 RC.

\section{The approval rate}

One thing that has to be mentioned when looking at the procedure and implementation of the Croatian Asylum Act is the extremely low approval rate of asylum seekers' applications. According to the UNHCR, ${ }^{62}$ from the first Asylum Act of 2004 until June 2011, there were 1,554 asylum requests but only 22 persons were granted refugee status, with a further 20 being granted subsidiary protection. Overall, that means that only $2.7 \%$ of applicants have received some sort of protection in Croatia. This low recognition rate can only suggest that something might be wrong with the system. Since the data used in asylum procedures are extremely difficult to gather, there is no way to be certain if protection has been denied to a legitimate claimant. The statistics seem to be improving, however. The first asylum claim in the history of Croatia was approved only in November 2006. The number of positively resolved claims started rising sharply in 2008. If we take the statistics from 2008 onwards, we obtain $3.8 \%$ for $2008,8.9 \%$ for 2009 , $4.4 \%$ for 2010 , and $2.7 \%$ for the first half of 2011. The increasing number of asylum claims is very noticeable. UNHCR, which has access to hearings and knows the decision-making process, says that the decisions became much better informed in 2008 and 2009 as a consequence of training and by looking at the experience of other countries (UNHCR interview). The Croatian Law Centre (CLC)

be allowed to submit the reasons against his expulsion and to have his case reviewed by, and be represented for the purpose before, the competent authority or a person or persons especially designated by the competent authority'.

${ }^{61}$ Cf C Tobler, 'Indirect Discrimination: A Case Study into the Development of the Legal Concept of Indirect Discrimination under EC Law' (Habilitation thesis, Basel 2005).

62 UNHCR (2011) 'Statistical Summary on Asylum Seekers in Republic of Croatia 20042011' <http://www.unhcr.hr/images/stories/news/stats/docs/07_2011/asylum_total. pdf> accessed 6 November 2011. 
representative stated: 'Since 2006 a lot of things have changed. Like political will. The system has really become functional' (CLC interview). It is not clear why exactly the number of approved applications has increased. There could be a variety of reasons for this (better training, political will, pressures from the EU, a better legal system, more eligible asylum seekers...). In any case, it is beyond the scope of this article to try to establish the clear causes of this increase, but it is certainly a positive trend.

We should compare Croatian statistics with the statistics of the EU countries. There have been 221,105 decisions on protection status in the EU in 2010, out of which there have been 55,095 positive first-instance decisions. ${ }^{63}$ This means that around $25 \%$ of applications were approved and that is only looking at the first-instance decisions. The figures were similar in 2008 and 2009. ${ }^{64}$ Not taking into account 2011, we can see that Croatia is still quite far from the EU average and there is definitely some room for improvement.

\section{Civil and political rights}

This subsection will cover the so-called civil and political rights of asylum seekers (although the political rights are notably absent). It will not go into the details of all the rights that exist in the international human rights framework, but will focus on those that warrant attention because they are being violated or because there are not enough safeguards against potential violations. It will focus on the freedom of movement and the question of detention.

The first problem with the freedom of movement of asylum seekers is that, although they are lawfully within the territory of Croatia - they have identity papers and are acknowledged as asylum seekers - their freedom of movement is strictly regulated. They have to come back to the ASRC by a certain hour, they have to inform the MOI if they wish to go anywhere for more than a few days, etc. These provisions could constitute a breach of article 12 ICCPR. ${ }^{65}$ This does not apply to people who reside in private accommodation (those who can afford it), because they only need to inform the police if they will be absent for an extended period of time.

${ }_{63}$ Eurostat (2010) 'Asylum applicants and first instance decisions on asylum applications in 2010' $5 / 2011$.

64 Eurostat (2009) 'Asylum applicants and decisions on asylum applications in Q1 2009' $30 / 2009$.

65 Article 12 ICCPR states: '1. Everyone lawfully within the territory of a State shall, within that territory, have the right to liberty of movement and freedom to choose his residence. 3. The above-mentioned rights shall not be subject to any restrictions except those which are provided by law, are necessary to protect national security, public order (ordre public), public health or morals or the rights and freedoms of others, and are consistent with the other rights recognized in the present Covenant'. 
While there are provisions in Croatian law that allow for the detention of asylum seekers and it cannot be said that cases of arbitrary detention regularly exist, there are several problems that have to be addressed. The law provides that an asylum seeker's freedom of movement can be curtailed to prevent the spread of infectious diseases, in order to establish identity, if there are grounds to believe that the application procedure is being misused, for security reasons, and to prevent flight to other countries (article 74 - loosely corresponding to article 18 APD and article $7 \mathrm{RD}$ ). Freedom of movement can be restricted for a maximum duration of three months with the possibility of an extension for another month in special circumstances. There is the possibility to appeal at the Procedural Court; however, this does not have a suspensive effect. ${ }^{66}$

The Asylum Act provides that the asylum seeker will not be punished for illegal entrance or presence on the territory of Croatia (article 21 ), provided that he or she applies for asylum without delay and if he or she gives valid reasons for illegal entrance or presence. However, the Aliens Act provides for the detention of aliens if they are caught in illegal presence in Croatia and need to be deported, or if their identity has to be established (article 100). According to the CPS representative, the Asylum Act and Aliens Act are often in conflict because asylum seekers are very often merely aliens illegally present in Croatia before they express their intention of seeking asylum. It is often not clear when the asylum seekers entered Croatia, but the MOI most often interprets their presence according to the Aliens Act and not according to the Asylum Act. This could constitute a breach of article $31 \mathrm{RC} \cdot{ }^{67}$ Another provision that allows for detention is contained in article 37 under which asylum seekers can be detained if they break the house rules of the ASRC. This decision is brought by the MOI and there is the possibility of an appeal with the Administrative Court. However, the appeal does not postpone the detention, and since the time taken to answer the appeal is notoriously long (in the range of 6-7 months, according to the interview with the Commission), there is effectively no right to appeal.

Although article 18(2) of the procedures directive stipulates that there should be a 'possibility of speedy judicial review,' the length of proceeding in Croatian courts is such that it clearly violates even this minimum standard. There is thus the possibility of asylum seekers being detained without due process and this could constitute a breach of article

${ }_{66}$ Suspensive effect means that the expulsion order cannot be executed until the appeal is accepted or rejected.

${ }^{67}$ Article 31 RC: ' 1 . The Contracting States shall not impose penalties, on account of their illegal entry or presence, on refugees who, coming directly from a territory where their life or freedom was threatened in the sense of article 1, enter or are present in their territory without authorization, provided they present themselves without delay to the authorities and show good cause for their illegal entry or presence'. 
9 ICCPR $^{68}$ and article 5 ECHR. In the case of a failed application, the asylum seeker would probably be deported and thus there would be no reasonable possibility to seek compensation in terms of these articles.

The Aliens Reception Centre (ARC) is a closed institution comparable to a prison with high walls, security cameras, barbed wire and armed guards. Aliens are brought there in order to establish their identity, or if they are in the process of deportation. Everybody has the right to state their intention of becoming an asylum seeker at any moment; however, the author observed that there were no visible brochures or information about the possibility of obtaining protection from Croatia. According to interviews with asylum seekers situated there, they all found out about the possibility of asylum through informal means (Jezevo interview). States have the obligation to inform people under their jurisdiction about their rights.

Although the ARC legal status is not that of a penitentiary institution, in practice it serves to limit the liberty of people detained in it, no matter what their reasons for being there are. Its purpose is not in accordance with the stipulated purpose - 'reformation and social rehabilitation'. This could constitute a breach of article 10 ICCPR. ${ }^{69}$

There is another problem with the ARC. There are no clear rules on how asylum seekers can be transferred to the ASRC in Kutina, as UNHCR noted (UNHCR interview). Access to psychological help is not easily provided to people held in the ARC. The biggest problem, however, is the already mentioned fact that people are held against their will as if they have committed a crime punishable by prison. There is a provision in the law

68 Article 9 ICCPR states: '1) No one shall be subjected to arbitrary arrest or detention. No one shall be deprived of his liberty except on such grounds and in accordance with such procedure as are established by law. 4) Anyone who is deprived of his liberty by arrest or detention shall be entitled to take proceedings before a court, in order that that court may decide without delay on the lawfulness of his detention and order his release if the detention is not lawful. 5) Anyone who has been the victim of unlawful arrest or detention shall have an enforceable right to compensation'.

Article 5 of ECHR states: '1. Everyone has the right to liberty and security of person. No one shall be deprived of his liberty save in the following cases and in accordance with a procedure prescribed by law: b. the lawful arrest or detention of a person for non-compliance with the lawful order of a court or in order to secure the fulfilment of any obligation prescribed by law; f. the lawful arrest or detention of a person to prevent his effecting an unauthorised entry into the country or of a person against whom action is being taken with a view to deportation or extradition. 4. Everyone who is deprived of his liberty by arrest or detention shall be entitled to take proceedings by which the lawfulness of his detention shall be decided speedily by a court and his release ordered if the detention is not lawful. 5 . Everyone who has been the victim of arrest or detention in contravention of the provisions of this article shall have an enforceable right to compensation'.

69 Article 10 ICCPR states: '3. The penitentiary system shall comprise treatment of prisoners the essential aim of which shall be their reformation and social rehabilitation. Juvenile offenders shall be segregated from adults and be accorded treatment appropriate to their age and legal status'. 
that asylum seekers should not be punished for illegal entry (article 21 corresponding to article 18 APD). However, if people are caught in illegal presence on the territory of Croatia, the Aliens Act has precedence and they are detained as illegal migrants - it does not matter if they express the intention to enter the asylum process. Thus, there is, according to the CPS representative, a conflict between the Croatian legal provisions, and it is very often the case that the more restrictive one takes precedence.

The Aliens Act does provide that people can be held in the ARC for three months and in exceptional circumstances for an additional three months, therefore for a maximum of six months. However, some of the people who took part in the interview had been held there for longer. An anonymous asylum seeker reported that she had been held there for seven and a half months and another asylum seeker had been held for six months (Jezevo interview). UNHCR reports that at least three people who were later granted some sort of protection spent some time at the ARC (UNHCR interview) which in effect means that the MOI does not do a good job in determining who is a genuine asylum seeker and whose freedom of movement should thus not be curtailed, and who is not. The problem according to UNHCR is the fact that the decision on denying the freedom of movement is not made by the people working in the ARC who are in direct contact with aliens and asylum seekers, but is made in the Department for Integration of MOI which lacks sufficient information (UNHCR interview). It is an unacceptable consequence of this lack of communication between MOI departments that some people who do not deserve to be detained end up in the ARC for extended periods of time (UNHCR interview).

\section{Social, economic and cultural rights}

This section focuses on the so-called social, economic and cultural rights of asylum seekers and people under protection. It continues drawing comparisons with provisions in European directives, and thus establishes the extent of Europeanisation. As in the previous section, not all rights are analysed, but only those relevant either because of what they are lacking, or because of their good implementation.

In practice there are a few different possibilities for the accommodation of asylum seekers. The first possibility is that the person is accommodated in the Asylum Seekers' Reception Centre (ASRC) in the town of Kutina. This accommodation is free (articles 38 and 39 - corresponding to articles 13 and 14 of the Reception Conditions Directive). The second option is that asylum seekers find their own accommodation somewhere in Croatia, but it is their responsibility and duty to inform the MOI about their whereabouts. The third possibility is that asylum seekers are accommodated in prison, a mental institution or the Aliens' Reception 
Centre (ARC), which serves as a deportation centre.

Article 106 allows for expulsion and the fine of asylum seekers that break the house rules of the ASRC, but only after their application has been decided on. This provision is problematic for it could lead to a breach of the non-refoulement principle on seemingly banal reasons such as breaking the house rules of the Centre. In a hypothetical situation, the asylum seeker could be granted refugee status, but under the provisions of this article he could nevertheless be expelled and some other country could return him to his home country. This article is in contradiction with the whole spirit of the Asylum Act and with human rights standards.

In the Asylum Seekers' Reception Centre, the author observed that it has professional staff and is quite well equipped, according to the law and regulations. The centre is well kept and there are several leisure areas including a gym. The observed minor problem is that the gym and a TV room are open only several hours per day. The Head of the Centre stated that the Centre has adapted itself to the needs of asylum seekers. For example, he said: 'We do not have any meals with pork anymore because many of the people here are Muslim. It would be too complicated to cook multiple dishes for this population'.

Since asylum seekers have the right to move freely in and out of the Centre, many of them go to the nearby town where the local library is well equipped with books in different languages, having been adapted to the needs of asylum seekers. The Head of the Centre and the MOI report that the local population is friendly towards asylum seekers, that there were no reported problems and that asylum seekers are being more and more integrated into local cultural or sports organisations (ASRC and MOI interviews).

According to the Head of the Reception Centre, women and families are separated from single men and they have a leisure room and gym reserved for them for a couple of hours every day. The accommodation appears to be sufficient for the current number of asylum seekers. The capacity is around 80 people, while in 2010 and before there were around 30 people present (Jezevo interview). However, it seems that due to the ever increasing trend in the number of asylum applications (eg the surge from 290 applications in 2010 to 326 in the first half of 2011), the current capacities will soon not be sufficient and the right to accommodation of future asylum seekers might be in jeopardy, although the Ministry of the Interior claims that they are ready for such situations (MOI interview). UNHCR generally does not object to the situation in the ASRC. The UNHCR representative said: "The only slight problem is that this Centre is not a permanent solution. We know it is a temporary solution, but as long as the accommodation standards are satisfactory - separate rooms for families, rooms where children can play... we are content' (UNHCR interview). 
The State is responsible for the integration of asylum seekers into cultural, economic and social life (article 50 - corresponding to article 12 of the Reception Conditions Directive). This is implemented by organising language courses, access to vocational training, and education about Croatian history and culture. The integration of asylum seekers into society is stipulated by a well-developed programme for language learning in the ARC. However, the CPS organises additional language courses which could indicate that demand is greater than what the State provides.

The local community in the town of Kutina where the Centre is located is friendly towards asylum seekers. This was reported both by the Head of the Centre, by asylum seekers, and by people with recognised refugee status (ARC, AS, Refugee interviews).

Asylum seekers have the right to receive humanitarian aid (article 35). They also have the right to employment (article 36 - corresponding to article 11 Reception Conditions Directive), but only after a year from lodging the asylum claim. This is a shortcoming both of the law and of the corresponding EU Directive. It is unreasonable to expect an asylum seeker to start working only after a year and it is also contrary to the principle that decisions on granting or refusing protection should be made as soon as possible. This in effect denies the right to employment to asylum seekers which could constitute a breach of Article 6 ICESCR. ${ }^{70}$

The integration of refugees and people under subsidiary protection is a great problem and is tied to the right to work. According to UNHCR, there are many cases where people who were granted some sort of protection leave the country (UNHCR interview). A refugee reports that he could not find a job, even after years of trying.

[...] I tried everywhere; in the Centre for Employment they told me that they do not have anything, that there is a big unemployment, and that it is very difficult now. I tried to find the job, I didn't find it. I see that they want to know where you come from (Refugee interview).

He later blames the MOI which is supposed to organise and coordinate integration in cooperation with other Ministries but fails to do so (Refugee interview). According to the Croatian government's Office for Human Rights, the new amendments to the law will explicitly mention aid for integration (OHR interview).

\footnotetext{
70 Article 6 ICESCR states: '1. The States Parties to the present Covenant recognize the right to work, which includes the right of everyone to the opportunity to gain his living by work which he freely chooses or accepts, and will take appropriate steps to safeguard this right. 2. The steps to be taken by a State Party to the present Covenant to achieve the full realization of this right shall include technical and vocational guidance and training programmes, policies and techniques to achieve steady economic, social and cultural development and full and productive employment under conditions safeguarding fundamental political and economic freedoms to the individual'.
} 
Asylum seekers who are minors have the right to elementary and secondary education just like Croatian nationals (article 32 - corresponding to article 10 Reception Conditions Directive). According to the MOI, children are being well integrated into the educational system. If the child understands the Croatian language sufficiently, they immediately put the child into the appropriate class and it does not matter if the school year has already started (MOI interview).

Asylum seekers have the right to social welfare and financial assistance (article 33 and 49 - corresponding to article 28 QD), unless they already have money or are employed or their cost of living is covered in some alternative way. This does not sufficiently specify the amount of money that an asylum seeker might have before he becomes ineligible to financial assistance. As such, it can be interpreted as possibly leading to the arbitrary denial of the right to social security as established in articles 9 and 23 ICESCR. Additionally, if asylum seekers have a constant inflow of money which is greater than the amount of the average monthly salary in Croatia (currently around EUR 730), then they do not qualify for free accommodation, free legal aid or any form of social welfare. Asylum seekers who qualify for social security still have an extremely low level of financial assistance. Currently the basic financial assistance for Croatian citizens amounts to around EUR 70 monthly. Asylum seekers are eligible to receive $20 \%$ of this amount which totals EUR 14 per month. Though in theory all the expenses for food and accommodation are covered by the State, access to libraries, the Internet, communication with relatives, etc, is supposed to be covered with this extremely small amount. This shortcoming is somewhat offset by the Croatian Red Cross which sometimes provides humanitarian aid like phone cards, games, medical supplies, etc (CRC Interview).

People who were granted some sort of protection have the right to financial assistance under the same conditions as Croatian nationals. However, UNHCR reports that there were cases when people did not qualify for any sort of protection, yet it was not possible for them to be returned to their country for some reason (the possibility of torture). These people do not receive any sort of aid; they are left completely to themselves (UNHCR interview). This is problematic from the procedural point of view (the obvious question that could be asked is: if there is the possibility of torture, why was protection not granted) and from the perspective of social rights (the State should ensure the possibility of achieving the minimal standard of living for people on its territory which people without status and without any aid cannot acquire). This could constitute a breach of article 9 ICESCR. ${ }^{71}$

71 Article 9: The States Parties to the present Covenant recognize the right of everyone to social security, including social insurance'. 
Asylum seekers have the right to emergency and necessary health care or other forms of health care if they were subjected to torture or rape (article 31 - corresponding to articles 15 and 20 of the Reception Conditions Directive). This is below the standard for citizens and could constitute a breach of article 12 ICESCR. ${ }^{72}$

People with special needs, like victims of trafficking, people with disabilities, people that have undergone torture, etc, are taken care of by different agencies. According to the CLC, world statistics suggest that around $20 \%$ of asylum seekers are victims of torture (CLC interview). The Asylum Commission can seek a medical and psychological examination to establish whether the person was indeed the victim of torture. However this happens rarely, as it is very costly. The practice in the EU is similar (CLC interview). One person who was granted refugee status had a disability and although his accommodation was provided free of charge, other integration aspects are still lacking. However, people with special needs warrant separate research that would pay due attention to the special problems they face in the Croatian asylum system.

\section{Conclusion and recommendations}

This section will make explicit what the findings of this paper say about the shortcomings of the asylum system in Croatia when it comes to human rights. It will enumerate the human rights of asylum seekers, refugees and people under subsidiary protection and assess their implementation in Croatia. It will focus on those rights whose exercise is either occasionally or regularly problematic, while the rights that are respected will simply be labelled as satisfactory.

Table 1 represent a summary of all the findings in this paper. They enumerate the rights from the international and European human rights documents that were analysed above and connect them to the findings. They give one of two marks: 'satisfactory' and 'attention needed'. They also assign the cause of the deficiencies in rights either to the EU (if the findings have shown that the deficiencies stem from the directives) or to Croatia (if the deficiencies do not stem from the directives).

\footnotetext{
72 Article 12: ' 1 . The States Parties to the present Covenant recognize the right of everyone to the enjoyment of the highest attainable standard of physical and mental health. 2 . The steps to be taken by the States Parties to the present Covenant to achieve the full realization of this right shall include those necessary for: (d) The creation of conditions which would assure to all medical service and medical attention in the event of sickness'.
} 
Table 1

\begin{tabular}{|c|c|c|c|c|}
\hline Right & $\begin{array}{l}\text { Document and } \\
\text { Article }\end{array}$ & $\begin{array}{c}\text { Conditions in } \\
\text { Croatia }\end{array}$ & $\begin{array}{l}\text { Weaknesses that } \\
\text { are the product of } \\
\text { Europeanisation }\end{array}$ & $\begin{array}{c}\text { Weaknesses that } \\
\text { are 'indigenous' to } \\
\text { Croatia }\end{array}$ \\
\hline $\begin{array}{l}\text { The right to } \\
\text { seek and enjoy } \\
\text { asylum from } \\
\text { persecution }\end{array}$ & $\begin{array}{l}\text { UDHR Article } \\
14\end{array}$ & $\begin{array}{l}\text { Attention } \\
\text { needed }\end{array}$ & $\begin{array}{l}\text { Problems with } \\
\text { definition (non-state } \\
\text { actors as actors of } \\
\text { protection, safe third } \\
\text { country, safe country } \\
\text { of origin); exclusion } \\
\text { clauses; issue with } \\
\text { interpretation; } \\
\text { guarantee of legal } \\
\text { assistance only for } \\
\text { appeals }\end{array}$ & $\begin{array}{l}\text { Accelarated } \\
\text { procedure can be } \\
\text { used for people } \\
\text { with health } \\
\text { problems; lack of } \\
\text { information about } \\
\text { the right in the } \\
\text { ARC; }\end{array}$ \\
\hline $\begin{array}{l}\text { The right } \\
\text { to effective } \\
\text { remedy }\end{array}$ & $\begin{array}{l}\text { ICCPR Article } \\
2 ; \text { ECHR } \\
\text { Article } 13\end{array}$ & $\begin{array}{l}\text { Attention } \\
\text { needed }\end{array}$ & $\begin{array}{l}\text { Appeal does not have } \\
\text { suspensive effect }\end{array}$ & $\begin{array}{l}\text { Unacceptably } \\
\text { long appeals } \\
\text { procedures before } \\
\text { the Court }\end{array}$ \\
\hline The right to life & $\begin{array}{l}\text { ICCPR Article } \\
\text { 6; ECHR } \\
\text { Article } 2\end{array}$ & Satisfactory & & \\
\hline $\begin{array}{l}\text { Freedom } \\
\text { from torture, } \\
\text { inhuman and } \\
\text { degrading } \\
\text { treatment or } \\
\text { punishment }\end{array}$ & $\begin{array}{l}\text { ICCPR Article } \\
7 ; \text { ECHR } \\
\text { Article } 3\end{array}$ & Satisfactory & & \\
\hline $\begin{array}{l}\text { Freedom } \\
\text { from slavery, } \\
\text { servitude and } \\
\text { forced labour }\end{array}$ & $\begin{array}{l}\text { ICCPR Article } \\
\text { 8; ECHR } \\
\text { Article } 4\end{array}$ & Satisfactory & & \\
\hline $\begin{array}{l}\text { The rights to } \\
\text { liberty and } \\
\text { security of } \\
\text { persons }\end{array}$ & $\begin{array}{l}\text { ICCPR Article } \\
\text { 9; ECHR } \\
\text { Article } 5\end{array}$ & $\begin{array}{l}\text { Attention } \\
\text { needed }\end{array}$ & & $\begin{array}{l}\text { Possibility of } \\
\text { detention for } \\
\text { breaking house } \\
\text { rules of ASRC; } \\
\text { Aliens Act taken to } \\
\text { have precedence } \\
\text { over Asylum } \\
\text { Act; de facto } \\
\text { impossible to } \\
\text { appeal }\end{array}$ \\
\hline $\begin{array}{l}\text { The rights } \\
\text { of detained } \\
\text { persons to } \\
\text { humane } \\
\text { treatment }\end{array}$ & $\begin{array}{l}\text { ICCPR Article } \\
10\end{array}$ & Satisfactory & & \\
\hline $\begin{array}{l}\text { Freedom from } \\
\text { imprisonment } \\
\text { for inability } \\
\text { to fulfil a } \\
\text { contract }\end{array}$ & $\begin{array}{l}\text { ICCPR Article } \\
11 ; \text { ECHR } \\
\text { Fourth } \\
\text { Protocol } \\
\text { Article } 1\end{array}$ & Satisfactory & & \\
\hline
\end{tabular}




\begin{tabular}{|c|c|c|c|c|}
\hline Right & $\begin{array}{l}\text { Document and } \\
\text { Article }\end{array}$ & $\begin{array}{c}\text { Conditions in } \\
\text { Croatia }\end{array}$ & $\begin{array}{l}\text { Weaknesses that } \\
\text { are the product of } \\
\text { Europeanisation }\end{array}$ & $\begin{array}{c}\text { Weaknesses that } \\
\text { are 'indigenous' to } \\
\text { Croatia }\end{array}$ \\
\hline $\begin{array}{l}\text { Freedom of } \\
\text { movement }\end{array}$ & $\begin{array}{l}\text { ICCPR Article } \\
12 ; \text { ECHR } \\
\text { Fourth } \\
\text { Protocol } \\
\text { Article } 2\end{array}$ & $\begin{array}{l}\text { Attention } \\
\text { needed }\end{array}$ & & $\begin{array}{l}\text { Possibility of } \\
\text { detention for } \\
\text { breaking house } \\
\text { rules of ASRC; } \\
\text { Aliens Act taken to } \\
\text { have precedence } \\
\text { over Asylum } \\
\text { Act; de facto } \\
\text { impossible to } \\
\text { appeal; people in } \\
\text { ASCR have limited } \\
\text { possibility to leave } \\
\text { the Center }\end{array}$ \\
\hline $\begin{array}{l}\text { The right of } \\
\text { aliens to due } \\
\text { process when } \\
\text { expelled }\end{array}$ & $\begin{array}{l}\text { ICCPR Article } \\
\text { 13; ECHR } \\
\text { Seventh } \\
\text { Protocol } \\
\text { Article } 1\end{array}$ & $\begin{array}{l}\text { Attention } \\
\text { needed }\end{array}$ & $\begin{array}{l}\text { Appeal does not have } \\
\text { suspensive effect }\end{array}$ & $\begin{array}{l}\text { Unacceptably } \\
\text { long appeals } \\
\text { procedures before } \\
\text { the Court de } \\
\text { facto deny the } \\
\text { possibility of } \\
\text { appeal }\end{array}$ \\
\hline $\begin{array}{l}\text { The right to a } \\
\text { fair trial }\end{array}$ & $\begin{array}{l}\text { ICCPR Article } \\
14 ; \text { ECHR } \\
\text { Article } 6\end{array}$ & $\begin{array}{l}\text { Attention } \\
\text { needed }\end{array}$ & & $\begin{array}{l}\text { Unacceptably } \\
\text { long appeals } \\
\text { procedures before } \\
\text { the Court }\end{array}$ \\
\hline $\begin{array}{l}\text { Freedom from } \\
\text { retroactive } \\
\text { criminal law }\end{array}$ & $\begin{array}{l}\text { ICCPR Article } \\
15 ; \text { ECHR } \\
\text { Article } 7\end{array}$ & Satisfactory & & \\
\hline $\begin{array}{l}\text { The right to } \\
\text { recognition } \\
\text { as a person } \\
\text { before the law }\end{array}$ & $\begin{array}{l}\text { ICCPR Article } \\
\text { 16; RC Article } \\
16\end{array}$ & Satisfactory & & \\
\hline $\begin{array}{l}\text { The right to } \\
\text { privacy }\end{array}$ & $\begin{array}{l}\text { ICCPR Article } \\
17 ; \text { ECHR } \\
\text { Article } 8\end{array}$ & Satisfactory & & \\
\hline $\begin{array}{l}\text { Freedom } \\
\text { of thought, } \\
\text { conscience } \\
\text { and religion }\end{array}$ & $\begin{array}{l}\text { ICCPR Article } \\
\text { 18; ECHR } \\
\text { Article 9; RC } \\
\text { Article } 4\end{array}$ & Satisfactory & & \\
\hline $\begin{array}{l}\text { Freedom of } \\
\text { opinion and } \\
\text { expression }\end{array}$ & $\begin{array}{l}\text { ICCPR Article } \\
\text { 19; ECHR } \\
\text { Article } 10\end{array}$ & Satisfactory & & \\
\hline
\end{tabular}




\begin{tabular}{|c|c|c|c|c|}
\hline Right & $\begin{array}{c}\text { Document and } \\
\text { Article }\end{array}$ & $\begin{array}{c}\text { Conditions in } \\
\text { Croatia }\end{array}$ & $\begin{array}{l}\text { Weaknesses that } \\
\text { are the product of } \\
\text { Europeanisation }\end{array}$ & $\begin{array}{c}\text { Weaknesses that } \\
\text { are 'indigenous' to } \\
\text { Croatia }\end{array}$ \\
\hline $\begin{array}{l}\text { Freedom from } \\
\text { propaganda, } \\
\text { and freedom } \\
\text { from } \\
\text { incitement to } \\
\text { racial religious } \\
\text { or national } \\
\text { hatred }\end{array}$ & $\begin{array}{l}\text { ICCPR Article } \\
20\end{array}$ & Satisfactory & & \\
\hline $\begin{array}{l}\text { Freedom of } \\
\text { assembly }\end{array}$ & $\begin{array}{l}\text { ICCPR Article } \\
21 ; \text { ECHR } \\
\text { Article } 11\end{array}$ & Satisfactory & & \\
\hline $\begin{array}{l}\text { Freedom of } \\
\text { association }\end{array}$ & $\begin{array}{l}\text { ICCPR Article } \\
22 ; \text { ECHR } \\
\text { Article } 11\end{array}$ & Satisfactory & & \\
\hline $\begin{array}{l}\text { The rights of } \\
\text { the family and } \\
\text { the right to } \\
\text { marry }\end{array}$ & $\begin{array}{l}\text { ICCPR Article } \\
\text { 23; ECHR } \\
\text { Article } 12\end{array}$ & Satisfactory & & \\
\hline $\begin{array}{l}\text { The rights of } \\
\text { the protection } \\
\text { of the child }\end{array}$ & $\begin{array}{l}\text { ICCPR Article } \\
24\end{array}$ & Satisfactory & & \\
\hline $\begin{array}{l}\text { The right of } \\
\text { participation } \\
\text { in public life }\end{array}$ & $\begin{array}{l}\text { ICCPR Article } \\
25\end{array}$ & Satisfactory & & \\
\hline $\begin{array}{l}\text { The right to } \\
\text { equality before } \\
\text { the law and } \\
\text { freedom from } \\
\text { discrimination }\end{array}$ & $\begin{array}{l}\text { ICCPR Article } \\
\text { 26; ECHR } \\
\text { Article 14; RC } \\
\text { Article } 3\end{array}$ & $\begin{array}{l}\text { Attention } \\
\text { needed }\end{array}$ & & $\begin{array}{l}\text { Possible indirect } \\
\text { discrimination due } \\
\text { to the length of } \\
\text { proceeding. }\end{array}$ \\
\hline $\begin{array}{l}\text { The rights of } \\
\text { minorities }\end{array}$ & $\begin{array}{l}\text { ICCPR Article } \\
27\end{array}$ & Satisfactory & & \\
\hline $\begin{array}{l}\text { The right to } \\
\text { work }\end{array}$ & $\begin{array}{l}\text { ICESCR } \\
\text { Article } 6\end{array}$ & $\begin{array}{l}\text { Attention } \\
\text { needed }\end{array}$ & & $\begin{array}{l}\text { Employment for } \\
\text { asylum seekers } \\
\text { possible only } \\
\text { after a year; no } \\
\text { assistance in } \\
\text { finding a job for } \\
\text { people under } \\
\text { protection }\end{array}$ \\
\hline
\end{tabular}




\begin{tabular}{|c|c|c|c|c|}
\hline Right & $\begin{array}{c}\text { Document and } \\
\text { Article }\end{array}$ & $\begin{array}{c}\text { Conditions in } \\
\text { Croatia }\end{array}$ & $\begin{array}{l}\text { Weaknesses that } \\
\text { are the product of } \\
\text { Europeanisation }\end{array}$ & $\begin{array}{c}\text { Weaknesses that } \\
\text { are 'indigenous' to } \\
\text { Croatia }\end{array}$ \\
\hline $\begin{array}{l}\text { The right to } \\
\text { fair conditions } \\
\text { of employment }\end{array}$ & $\begin{array}{l}\text { ICESCR } \\
\text { Article } 7\end{array}$ & Satisfactory & & \\
\hline $\begin{array}{l}\text { The right to } \\
\text { join and form } \\
\text { trade unions }\end{array}$ & $\begin{array}{l}\text { ICESCR } \\
\text { Article } 8\end{array}$ & Satisfactory & & \\
\hline $\begin{array}{l}\text { The right to } \\
\text { social security }\end{array}$ & $\begin{array}{l}\text { ICESCR } \\
\text { Article 9; } \\
\text { Article } 23\end{array}$ & $\begin{array}{l}\text { Attention } \\
\text { needed }\end{array}$ & & $\begin{array}{l}\text { Extremely } \\
\text { low financial } \\
\text { assistance for } \\
\text { asylum sekers; } \\
\text { unclear rules } \\
\text { on eligibility; } \\
\text { some people do } \\
\text { not qualify for } \\
\text { anything and are } \\
\text { left to themselves. }\end{array}$ \\
\hline $\begin{array}{l}\text { The right to } \\
\text { protection of } \\
\text { the family }\end{array}$ & $\begin{array}{l}\text { ICESCR } \\
\text { Article } 10\end{array}$ & Satisfactory & & \\
\hline $\begin{array}{l}\text { The right to } \\
\text { an adequate } \\
\text { standard of } \\
\text { living }\end{array}$ & $\begin{array}{l}\text { ICESCR } \\
\text { Article } 11\end{array}$ & Satisfactory & & \\
\hline $\begin{array}{l}\text { The right to } \\
\text { health }\end{array}$ & $\begin{array}{l}\text { ICESCR } \\
\text { Article } 12\end{array}$ & $\begin{array}{l}\text { Attention } \\
\text { needed }\end{array}$ & & $\begin{array}{l}\text { Only emergency } \\
\text { healthcare } \\
\text { provided to } \\
\text { asylum seekers }\end{array}$ \\
\hline $\begin{array}{l}\text { The right to } \\
\text { education }\end{array}$ & $\begin{array}{l}\text { ICESCR } \\
\text { Article 13; } \\
\text { ECHR First } \\
\text { Protocol } \\
\text { Article } 2\end{array}$ & Satisfactory & & \\
\hline $\begin{array}{l}\text { The right to } \\
\text { free basic } \\
\text { education }\end{array}$ & $\begin{array}{l}\text { ICESCR } \\
\text { Article } 14 ; \mathrm{RC} \\
\text { Article } 22\end{array}$ & Satisfactory & & \\
\hline $\begin{array}{l}\text { The right to } \\
\text { culture }\end{array}$ & $\begin{array}{l}\text { ICESCR } \\
\text { Article } 15\end{array}$ & Satisfactory & & \\
\hline \multicolumn{5}{|c|}{$\begin{array}{l}\text { Note: UDHR - Universal Declaration of Human Rights; ICCPR - International Covenant } \\
\text { on Civil and Political Rights; ICESCR - International Covenant on Economic, Social } \\
\text { and Cultural Rights; ECHR - European Convention on Human Rights; RC - Refugee } \\
\text { Convention. } \\
\text { Note 2: Only relevant articles were selected in Tables 1,2, } 3 \text { and 4. Especially regarding } \\
\text { RC, only articles that apply universally to all people (and not just to foreigners). }\end{array}$} \\
\hline
\end{tabular}


The assessment of the compatibility of the Croatian asylum system with the international human rights standards has shown that the level of potential and actual human rights violations is not very high and that the main characteristic of the Croatian asylum system is its very quick and positive development. There are only a few areas of human rights that warrant attention so that they become fully in line with human rights standards, while the majority of areas have a satisfactory human rights record.

It has been established beyond doubt that the extent of Europeanisation is high. Numerous examples of incorporating European directives into the law or into practice have been demonstrated by pointing to articles in the Croatian Asylum Act that correspond to articles in the directives.

It is clear that without the establishment of an asylum system in the first place there would be no possibility of asylum seekers having any rights whatsoever. In respect of the initial creation of the asylum system, the effect of Europeanisation in Croatia is overwhelmingly positive from the perspective of human rights. In this sense we can agree with Thielmann and El-Enany ${ }^{73}$ that the Europeanisation of asylum has strengthened refugee protection.

However, when it comes to respect and protection of individual rights, the human rights record of Europeanisation is mixed. Some rules and practices that were directly inherited from the EU directives clearly do not conform to human rights standards. Perhaps the single biggest shortcoming is the definition of refugees that allows for a very restrictive interpretation and opens the possibility of refoulement. Numerous other examples of deficiencies in the directives have been highlighted through analysis and by using secondary sources and they have been linked to the deficiencies in the Croatian asylum system.

On the other hand, the findings have shown that the majority of deficiencies in the Croatian asylum system do not stem from Europeanisation itself, but are 'indigenous' Croatian problems. However, it was found that Europeanisation did open the possibility for some major human rights violations, most notably, problematic exclusion clauses. On a positive note, it was seen that although certain problematic provisions from the directives have been incorporated in Croatian law, they are not utilised in practice. For example, the accelerated procedures are not used, and neither are the concepts of safe country of origin and safe third country. These examples are laudable, but the question is whether they can remain in place under the pressure of Europeanisation.

\footnotetext{
${ }^{73}$ Thielemann and El-Enany (n 20).
} 
Other positive examples can be found in practice. In this paper, it has seemed that people working in the Croatian asylum system have often amended the legal provisions that are not wholly in conformity with human rights standards. Examples of good practice include the Commission's use of the benefit of doubt in favour of asylum seekers, well-organised and well-run accommodation services, good access to legal aid, NGOs' work, etc. The conclusion is therefore that, surprisingly, it seems that Croatian asylum practice is more aligned with human rights standards than envisaged either by Croatian law or EU directives.

The thing to note is that Croatia cannot influence European asylum policies before entering the EU and this fact highlights the unequal position of Europeanisation that was first put forward by Olsen. ${ }^{74}$ Until Croatia has a greater influence on the workings of the EU, it probably remains beyond its reach to change the provisions that have been incorporated and that were found in the directives.

What Croatia can change, however, are the human rights deficiencies that are 'indigenous' to Croatia. From the findings we can conclude that the greater role in the problems with the Croatian asylum system lies with Croatia rather than with Europeanisation. It now remains to give recommendations on what is necessary for the improvement of the Croatian asylum system. The recommendations will focus on what the author finds the most urgent, what is feasible and what does not depend on the EU:

1) Abandon the provision that people with health problems can be subjected to an accelerated procedure.

2) Inform aliens in the ARC of their right to seek asylum.

3) Establish guidelines in which asylum procedures have priority in the Administrative Court.

4) Abandon the provision that asylum seekers can be detained for breaking the house rules of the ASRC.

5) Establish clear guidelines on when the Asylum Act has precedence over the Aliens Act and in which situations asylum seekers can be transferred from the ARC to the ASRC.

6) Abandon the provision that requires asylum seekers to report to the ASRC every evening.

7) Allow asylum seekers the right to work as soon as they lodge an application for asylum.

8) Provide assistance to people under protection in search of employment.

74 Olsen (n 11). 
9) Increase the amount of financial assistance for asylum seekers to the same basic level that Croatian citizens have.

10) Establish clear guidelines on eligibility for social welfare.

11) Allow full access to healthcare to asylum seekers and people under protection.

These recommendations complete the intention of this paper. It simply remains for them to be implemented in order to improve the human rights protection of asylum seekers. 